\title{
Understories of the political forest: a mobile feminist political ecology?
}

Commentary on Nancy L. Peluso's 'The Remittance Forest: Turning Mobile Labour into Agrarian Capital.

Rebecca Elmhirst

School of Environment and Technology, University of Brighton, Brighton, UK

Correspondence: Rebecca Elmhirst (email: r.j.elmhirst@brighton.ac.uk)

Singapore Journal of Tropical Geography DOI 10.1111/sjtg.12227

Published online December 2017

In this important article, Nancy Peluso revisits the montane forests of Java to examine the effects of women's transnational labour migration and remittance practices, and in so doing, rethinks the 'political forest', a concept she crafted in collaboration with Peter Vandergeest (Peluso and Vandergeest, 2001). The 'political forest' continues to be an important theme in studies of enclosure and resource access in Southeast Asia, representing a territorialized constellation of power constituted by ideas, practices and institutions that seek to regulate peoples' access to resources, providing recognition and legitimacy to some, whilst excluding and criminalizing others (Peluso and Vandergeest, 2001; Elmhirst, 2011). The concept was developed in part through Peluso's ethnographic work in the late 1980s in forest villages whose residents lived and cultivated land adjacent to or enclaved within the political forest- teak and non-teak forest areas under the control of the state (Peluso, 1992; Peluso et al., 2010). Thirty years on, the relationships between forest workers, the forest landscape and the State Forestry Corporation has been radically transformed through the transnational labour migration of women and girls, and the effects of remittances saved from their paid domestic work in Hong Kong and elsewhere. Peluso describes the unexpectedly large and fancy houses built on land 'borrowed' from the state, listening in on cell phone calls from returning women waiting at the international airport, and livelihoods now based somewhat surprisingly on small-scale but commercial dairy farming: tell-tale signs that this is an emblematic remittance landscape (McKay, 2005), or more precisely, a 'remittance forest'. Mobile labour and money has enabled a shift in the room for manoeuvre accorded to low paid forest workers whose livelihoods hitherto depended on being granted 'privileged' access to forest land and work opportunities. The politics and practices of enclosure and access are thus challenged and reworked by the possibilities arising through women's mobile labour, their remittances and family multi-local livelihoods based on the managed cultivation of elephant grass below the pine trees of the state forest.

Peluso's telling of these various 'understories' is characteristically intriguing and insightful, and for $m e$, it suggests many strands for further elucidation and exploration through a mobile feminist political ecology framing. Of these possibilities, I focus here on two that are interconnected, and remain attached to theories of resource access and control. First, Peluso makes the important point that the experiences of this community reveal the invisible ways that forest management and the realisation of the political forest is predicated on women's labour, and that the remittance forest is a regendered forest. In Indonesia, where transnational labour is predominantly female (Gaspar and Truong, 2014), the spectacle of remittance landscapes produced through women's migration has brought about a reappraisal of the value and significance of women's productive labour in landscape production past and present. The work I have done in the Indonesian province of Lampung tells a 
similar story of changing relationships between gendered labour, land and livelihood in the context of women's transnational migration. As was the case in the forest communities of Java that Peluso describes, prevailing gender norms positioning women as 'managers' of household budgets and that place few normative restrictions on men's engagement in domestic tasks, enabled women to take up long contracts as domestic workers overseas, in this case, investing their remittances in oil palm and in children's education. However, this assemblage of gendered mobile labour, landscape and livelihood is one that mutates and shifts, revealing the importance of linking gender analysis to generational dynamics.

During fieldwork I conducted in 2005 (ten years after my first fieldwork in the community), one of the farmers who had also worked as a foreman at a nearby sugar plantation had taken on a new role as an intermediary connecting Jakarta-based labour brokers with the community. His own wife was among the first group of women to take up a contract as a domestic worker, and during the month that I was there, around 45 women left, initially to Jakarta, and then onwards to Hong Kong and Malaysia. I later learned that almost all women aged between 25 and 40 had followed, leaving children in the care of their husbands and grandparents. Returning to the community a decade later, I found that women's engagement in transnational migration had waned, and instead many of the daughters (and some sons) of these pioneer transnational migrant women were capitalising on the education their mothers had invested in, and were now working in factories in the Greater Jakarta Metropolitan Region - work that was deemed to be better paid, more skilled and requiring less 'spatially stretched' modes of care for children and elders. The oil palm, however, remained, and if anything, had expanded, replacing any last vestiges of subsistence agriculture in rice fields and home gardens (Elmhirst and Darmastuti, 2015).

The reassembling of (forest) labour and landscapes through transnational migration thus invites a more intersectional analysis of gendered intergenerational relationships - how these emerging conjunctures create new possibilities (and forego others) for youth as they grow up and foster new configurations of the political forest. In Peluso's study, for example, the stories not yet told also concern young women and men - children left behind, whose labour may be required to collect elephant grass and care for the dairy cows, but whose aspirations may lie far from forest dependence. What kinds of pathways might be opening up (or indeed closing down) for this new generation, as inter-generational power shapes access to resources as it intersects with other relationships including gender and class (Park and White, 2017)?

There are potentially fruitful possibilities in applying a more explicitly intersectional analysis of gender produced through ethnicity, life course and age (Lykke, 2010) in the remaking of the remittance political forest. This is particularly so in contexts where past and present migrations bring different ethnic groups together, and where gendered ethnic differences may be elaborated and politicised. We have found something like this in our work on the impacts of oil palm in East Kalimantan where communities are made up of different ethnic groups, with distinctive gender dynamics that are in turn associated with each community's socio-ecological history and relationship with the state (Elmhirst et al., 2017). A small part of our wider study has noted the significance of cross-border migration between East Kalimantan and Malaysia related to oil palm labour markets. Returning oil palm labourers (originally from Sulawesi) are investing their skills, capital and planting material in East Kalimantan's oil palm frontier, effecting small-scale but incremental acquisitions of disputed 'state forest' land, adding a further layer of dispossession to Dayak communities with ancestral claims. Combining the intersectional analysis we offered with Peluso's conceptualisation of the 'remittance forest' offers huge scope for a mobile feminist political ecology that attends more 
carefully to the new configurations of power that emerge where remittances afford differentiated agency to those contesting resource access and control in forest landscapes.

A further dimension to intersectionality concerns the ways in which gender (and other forms of social difference) are forged in and through engagements with nature and the environment, and this offers a second potentially fruitful extension of Peluso's analysis here. Material feminisms take seriously the materiality of the natural world in ways that redefine relationships among the natural, the human and the non-human, and the agency of nature in complex conjunctions of culture, history, technology, biology and the environment (Collier and Ong, 2005). Peluso herself has undertaken this kind of work in her situated socio-natural history of rubber, which explores the coconstitutive processes between human and nature's agency in naturalizing and commodifying rubber. In Peluso's study of the remittance forest, the role of elephant grass in the conjuncture of gendered mobile labour, remittances and forest landscape change is one worth telling through such a socio-natural history. Elephant grass, sometimes referred to as Napier grass (Pennisetum purpureum) has its own migration history, originating in Africa, and intentionally introduced to many tropical regions in the early part of the $20^{\text {th }}$ century as a forage crop (FAO, 2013). Its slope stabilizing properties means it has been promoted in conservation agriculture interventions (Agus et al., 1999). Whilst its spatial history and properties are on the face of it, less geopolitically riveting than the story of rubber, there is room for exploring how it has been co-constituted within the tense racialized politics of swidden agriculture in forested landscapes, as has been the case for other types of invasive grasses such as Imperata cylindrica, (Dove, 1983).

Like rubber, elephant grass is commodified, or at least, embedded in globalising commodity chains. Indonesia's dairy commodity chain links smallholders with major Indonesian milk processing companies (Indomilk and Ultra Jaya) and multinationals (Danone, Frisian Flag and Nestle), and its expansion is linked to growing regional markets for milk (including powdered baby milk) as Southeast Asian diets become more 'westernized'. A recent industry report noted the role of milk exports as franchise coffee shops such as Starbucks in Singapore and Hong Kong now use Greenfields fresh milk from Indonesia replacing supplies from Australia. There may be multiple and entangled ways in which the remittance forest landscapes of upland Java are produced through ties with Hong Kong and the gendered reproductive geographies of infant formula and coffee shops located close to the public spaces where transnational domestic workers routinely gather on Sundays. A mobile and material feminist political ecology analysis is enriched by what can be learned from Peluso's insights from the understory in a forest worker's settlement in the volcanic landscapes of Java, and its relational ties with other places that serve to destabilize the 'methodological nationalism' (Gasper and Truong, 2014) of a state-centred conceptualisation of the political forest.

Agus F Garrity DP Cassel DK Mercado A (1999) Grain crop response to contour hedgerow systems on sloping Oxisols. Agroforestry Systems 42 (2), 107-120.

Collier SJ Ong A (2005) Global assemblages, anthropological problems. In Ong A, Collier SJ (eds) Global Assemblages: Technology, Politics and Ethics as Anthropological Problems. 3-21 Blackwell, Oxford.

Dove MR (1986) The practical reason of weeds in Indonesia: peasant vs state views of Imperata and Chromolaena. Human Ecology 14 (2), 163-190.

Elmhirst R (2011) Migrant pathways to resource access in Lampung's political forest: Gender, citizenship and creative conjugality. Geoforum 42 (2), 173-183. 
Elmhirst R Darmastuti A (2015) Material feminism and multi-local political ecologies: rethinking gender and nature in Lampung, Indonesia. In Lund R Doneys P Resurrección BP (eds) Gendered entanglements: re-visiting gender in rapidly changing Asia, 177-206. NIAS Press, Copenhagen.

Elmhirst R Siscawati M Basnett BS Ekowati D (2017) Gender and generation in engagements with oil palm in East Kalimantan, Indonesia: insights from feminist political ecology. The Journal of Peasant Studies 44 (6), 1137-1159.

FAO (2013) Grassland species profiles: Pennisetum purpureum. Rome, Italy: FAO. http://www.fao.org.ag/AGP/AGPC/doc/Gbase/data/pf000301.htm. [last accessed 28/11/17]

Gasper D Truong TD (2014) 'Women in motion' in a world of nation-states, market forces, and gender power relations. In Truong TD Gasper D Handmaker J Bergh SI (eds) Migration, Gender and Social Justice: Perspectives on Human Insecurity, 367-386. Springer Publications, Dordrech.

International Finance Corporation (2011) Dairy Industry Development in Indonesia. Report by the IFC of the World Bank.

https://www.ifc.org/wps/wcm/connect/93f48d00470e3bf883ffd7b2572104ea/Dairy+Industry+Deve lopment-2011.pdf?MOD=AJPERES [last accessed 28/11/2017]

Lykke N (2010). Feminist studies: A guide to intersectional theory, methodology and writing. Routledge, London.

McKay D (2005) Reading remittance landscapes: Female migration and agricultural transition in the Philippines. Geografisk Tidsskrift-Danish Journal of Geography 105 (1), 89-99.

Peluso NL (1992) Rich forests, poor people: Resource control and resistance in Java. University of California Press, Berkeley.

Park CMY and White B (2017) Gender and generation in Southeast Asian agro-commodity booms. The Journal of Peasant Studies 44 (6), 1103-1110.

Peluso NL (2012) What's nature got to do with it? A situated historical perspective on socio-natural commodities. Development and Change 43 (1), 79-104.

Peluso, NL Vandergeest P (2001) Genealogies of the political forest and customary rights in Indonesia, Malaysia, and Thailand. The Journal of Asian Studies 60 (3), 761-812. 